\title{
MONITORING OF THE ACTIVITY OF PUBLIC PROCUREMENT SYSTEM IN COUNTRIES OF EUROPEAN UNION AND UKRAINE
}

\author{
Iryna Ksonzhyk' ${ }^{1}$, Maryna Dubinina² \\ Mykolayiv National Agrarian University, Ukraine
}

\begin{abstract}
The research objective is to study and summarize the experience of the European Union countries in the field of public procurement monitoring; to study the activities that form its mechanism; to analyse forms of monitoring. Also, the current state, problems and prospects of creation and implementation of the mechanism for public procurement monitoring in Ukraine are studied; administrative and corruption risks are revealed. Methodology. Theoretical and methodological backgrounds of the research are formed on the basis of the provisions, categories, and concepts of economic theory, national and world economy, strategic development of public procurement, modelling. Laws and regulations that are regulators of the public procurement system and its monitoring, the works of domestic and foreign scientists on investigated issues were of greater importance. The system-structural analysis and synthesis, general scientific methods and methods of economic research are used to analyse and evaluate the phenomena and processes that accompany the functioning of the public procurement market and the mechanism for its monitoring. In particular, historical and dialectical methods (when studying the development of public procurement system in Western countries, the definition of stages and trends in its formation, the development and adoption of treaties for the regulation of public procurement within the European Union); method of expert assessments (for assessing the regulatory and legal support for public procurement monitoring); abstractlogical method (when establishing the factors for the formation of a monitoring mechanism in the field of public procurement in Ukraine, in particular, the institutional and organizational-economic features of its implementation, when assessing the criteria and performance indicators for the functioning of the monitoring system and its impact on the public procurement market, for theoretical generalization and conclusions formation). Results. The results of the research showed that the system of public procurement in the member countries of the European Union and its monitoring processes are still in the process of reforming, despite being the most organized, open, and predictable in the world. At the same time in Ukraine, the process of developing and implementing a mechanism for monitoring public procurement is only a few years old. At the same time, the development of the field of public procurement and the mechanism for its monitoring is accelerating, which is conditioned both by the position of civil society and by the presence of significant corruption risks. Practical implications. The study of the experience of the public procurement monitoring system in the EU countries makes it possible to use the result (in the form of conclusions and generalizations) to adapt foreign monitoring instruments to the domestic realities of the public procurement market in order to achieve maximum effect in the form of budgetary savings. Value/originality. Harmonization of the organizational and economic mechanism for public procurement and its monitoring in the countries of the European Union and Ukraine will provide a mutual opportunity for both foreign and domestic economic entities to become full participants in the public procurement markets; will make procurement, conducted in Ukraine, clear and accessible to foreign participants.
\end{abstract}

Key words: monitoring, public procurement, observations, directives, regulatory framework, procedure, electronic platforms.

JEL Classification: H83, M48, F15, K33, Z39

\footnotetext{
Corresponding author:

${ }^{1}$ Department of Accounting and Taxation, Mykolayiv National Agrarian University.

E-mail: iryna_ksonzhyk@meta.ua

${ }^{2}$ Department of Accounting and Taxation, Mykolayiv National Agrarian University.

E-mail: dubinina@mnau.edu.ua
} 


\section{Introduction}

Public procurement in countries of the European Union is a powerful tool for achieving social goals. Such goals include the social responsibility of business entities, development of innovation, improvement of labour relations, measures aimed at improving the health of the population, environmental protection, combating climate change, and other socio-economic and environmental issues.

It should be borne in mind that public procurement contracts constitute the largest share of GDP and the state budget of any country in the European Union. According to the Evaluation Report (2016) published by the European Commission, the volume of public procurement in the European Union in 2014 was 1800 billion Euros. Thus, in the EU, procurement by the Member States corresponds to about 19\% of their GDP, and the company whose business is directly dependent on these procurements provides more than 30 million jobs. Such index itself justifies the need to monitor the operation of public procurement systems.

The Oxford English Dictionary (OED) defines the verb "to monitor" as "to observe and check the progress or quality of (something) over a period of time; keep under systematic review" (Oxford English Dictionary, 2018).

According to another definition, "monitoring is a discontinuous (regular or irregular) series of observations over time conducted to determine the degree of compliance with a stated standard or the degree of deviation from the expected norm" (Hellawell, 1991). Monitoring is only meaningful when a desirable condition depending on the tasks or goals is predefined. The role of monitoring is to assess whether such goals (tasks) have been achieved (performed) (Public Procurement. Performance Measurement, 2011).

The monitoring of public procurement includes absolutely all systematic observations of the public procurement system, conducted on the basis of homogeneous approaches in order to evaluate the functioning and development of this system over time and to determine if the desired (plan) state established by political leadership has been achieved.

The concept of monitoring, as defined above, should be distinguished from the methods and procedures used to identify and eliminate violations of public procurement rules (audits, inspections, compliance monitoring). Whereas detecting and eliminating violations of public procurement rules is an important tool for achieving their goals, monitoring is a concept that is much broader and not limited to solely compliance control (Public Procurement. Performance Measurement, 2011).

\section{Analysis of public procurement monitoring system in countries of the European Union}

In EU member states, the practice of public procurement is based on the cooperation of European companies with the state. Active development of the system of public procurement in the western countries began in the second half of the XX century when there was a need for post-war reconstruction and construction of large infrastructure objects. Treaties on the regulation of public procurement within the framework of the European Union countries (1971, 1976) were developed and adopted.

Within the EU, the most important aspects of public procurement are unified, making the legislation of different Member States quite similar in the field of public procurement. At the same time, however, in their attempts to harmonize the norms of monitoring activities, the EU stopped at the minimum, which is necessary to enable the European Commission to supplement the information that can be obtained from messages published in the Tenders Electronic Daily (TED) - the general EU database (Articles 83-85 of the new Directive 2014/24/EU) (Directive 2014/24/EU of the European Parliament, 2014).

The new public procurement directives, adopted in 2014, require the Member States to "monitor compliance with public procurement rules." This requirement is defined by the basic rules of monitoring activities. Therefore, it is necessary to ensure that the monitoring bodies in the Member States have a competence whose scope would include defining the problems associated with the application of public procurement rules and bringing them to the attention of the relevant ultimate audit institutions. It is also important to ensure open access to the results of such monitoring.

The EU Member States are also required to submit statistical reports every three years indicating "(...) the most common causes of misuse of regulations or legal uncertainty, including possible structural or periodic problems related to the application of regulations, at the level of SMEs involved in public procurement, as well as on the prevention, detection of fraud, corruption, conflicts of interest or other serious violations during the procurement process and their proper reporting."

Thus, in the EU, the main objective of monitoring is to ensure the proper application of provisions of directives in the field of public procurement (Shatkovskyi, BruunNielsen, 2016).

As a rule, monitoring of public procurement in EU countries includes such activities as: data collection; analysis; dissemination of information on various aspects of public procurement (such as transparency, openness, competitiveness, and efficiency).

The information collected during the monitoring is useful for the purpose of developing rules, determining the effectiveness of financial costs, and developing conclusions on compliance with the fundamental principles of publicprocurementand theimplementation of predefined tasks and plans. The monitoring results provide a basis for the preparation of regular reports on the functioning of the procurement system, and 
in particular - for developing recommendations and proposals for its further development.

It is necessary to monitor this system in order to make well-founded decisions regarding the further development of the public procurement system.

In order for monitoring to produce meaningful results, it is necessary to fulfil a number of conditions. Firstly, the goals and objectives of rules of the public procurement system should be consistent in time, since otherwise, it will be difficult to compare the results obtained during the monitoring process. Secondly, the availability of high-quality, reliable data plays the crucial role. Thirdly, for the effective monitoring, it is necessary that the specialists who deal with them have skills in analysing and preparing reports. They should understand which information is useful, how to collect it, how to process the collected data, how to draw conclusions, and how to present the results obtained during the monitoring. Fourthly, the effectiveness of monitoring depends on the support, guidance, and actions of the management (Public Procurement. Performance Measurement, 2011).

There are three main forms of monitoring: regulatory compliance audit, performance parameters estimation, compliance monitoring (Fig. 1).

1. Regulatory compliance audit (Procedural Compliance).

Thistype of monitoring means the audit of the activities of tender organizers in terms of the formal fulfilment of their legal requirements. Such monitoring is carried out through checks (inspections) of the legality of acts taken by the organizers of tenders (for example, qualification selection of economic entities or determination of the winner of a tender) or their inactivity. It should result in an increase in the proportion of competitive procedures (Public Procurement. Performance Measurement, 2011).

Examples of departments, which carry out regulatory compliance audit, are Bulgarian Public Procurement Agency, Polish Public Procurement Office, Public Procurement Office in Slovakia, as well as Romanian National Authority for Regulating and Monitoring Public Procurement.

The monitoring of public procurement, above all, is to verify compliance with established procedural standards or the effectiveness of public procurement, which are important functions of public administration. There are different approaches to the organization of this type of monitoring and different ways of determining and measuring the level of procurement efficiency, but the most obvious criterion in this regard is the level of efficiency of the use of taxpayers' funds (Shatkovskyi, Bruun-Nielsen, 2016).

2. Performance parameters estimation/measurement.

This type of monitoring focuses on assessing the performance of the procurement system in terms of efficiency and effectiveness. To carry out such an assessment, monitoring bodies are required to collect and process a wide range of data on procurement processes. These data as a whole can be called the indicators of procurement (Public Procurement. Performance Measurement, 2011).

3. Compliance monitoring.

Compliance monitoring can also be conducted for specific purposes, for example, to verify compliance with international standards and international obligations of Ukraine (regarding the approximation of its public procurement legislation to the relevant EU directives

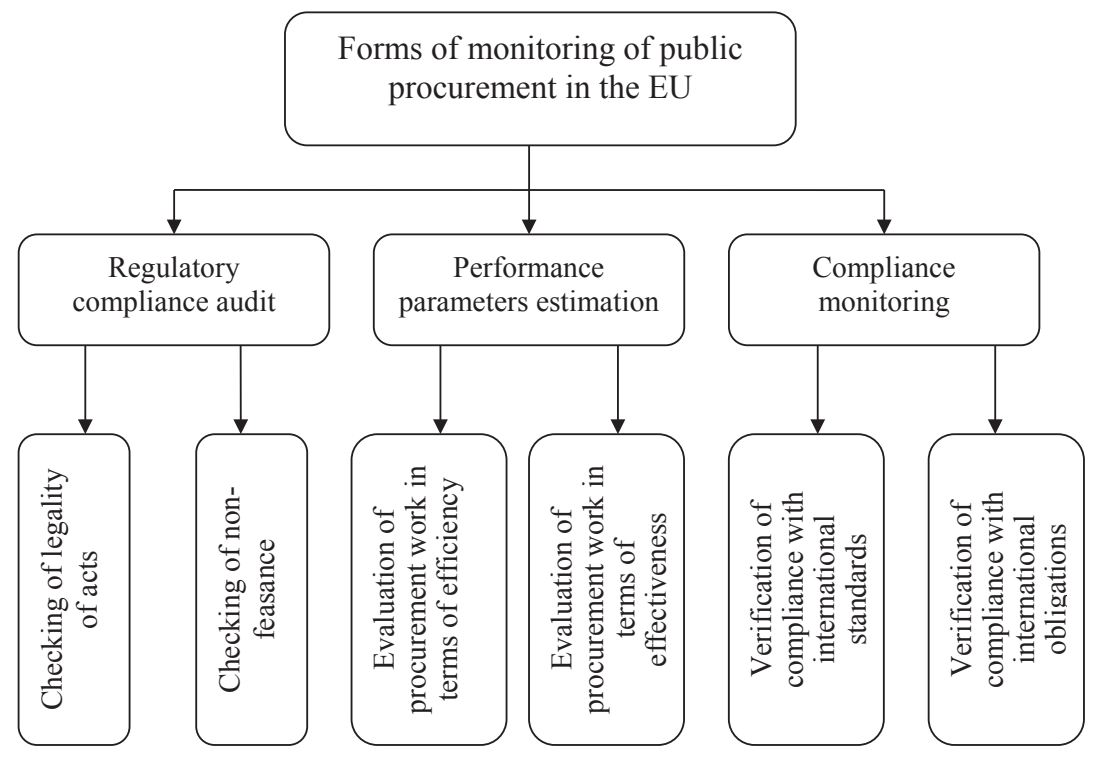

Fig. 1. Forms of public procurement monitoring in the member states of the European Union

Source: compiled by the authors according to the research results 
or other international standards) (Shatkovskyi, BruunNielsen, 2016).

\section{Peculiarities of public procurement monitoring in Ukraine}

In Ukraine, the monitoring of procurement is regulated by the Law of Ukraine "On Public Procurement", namely, paragraph 11 of part one of Article 1 (from the moment of the enactment of this legislative act) gives definition to this economic category, and describes it as "... an analysis of customer compliance with the law in the field of public procurement at all stages of the procurement procedure through systematic observation and analysis of information through the electronic procurement system" (On Public Procurement, 2015).

Section II "State regulation and control in the field of procurement" of the same Law also states that "... Procurement monitoring is carried out by a central executive body that implements state policy in the field of public financial control and its local authorities." In addition, Section II identifies those responsible for monitoring procurement in Ukraine, as well as six entities for control and monitoring of public procurement (Fig. 2).

The aforementioned Law states that the procedure for monitoring is determined by the central executive body, which ensures the formation and implementation of the state financial policy.

The general vision of the procurement monitoring mechanism, which was reflected in the Law of Ukraine "On Public Procurement", did not allow for the detection of abuses in this field and the mechanism of bringing to responsibility was ineffective. This was confirmed by the practical activity of ProZorro electronic public procurement system.
Therefore, the new stage in the implementation of monitoring of public procurement in Ukraine was the adoption of the Law of Ukraine No. 4738-d "On Amendments to the Law of Ukraine "On Public Procurement" and some Laws of Ukraine on Procurement Monitoring" by the Verkhovna Rada on December 21, 2017, which extends the powers of the State Audit Service of Ukraine (hereinafter referred to as the SASU) in the field of monitoring of public procurements, which will improve the efficiency of tender procedures and reduce the effectiveness of corruption schemes (On Amendments to the Law of Ukraine "On Public Procurement" and some Laws of Ukraine on Procurement Monitoring, 2017).

Before the adoption of this law, auditors of the SASU did not have the tools to prevent violations at all stages of procurement. They could only react after a bid after the contracts had already been signed and a transfer of funds was made. The auditors' recommendations regarding the termination of contracts were not binding and were often ignored by offenders. Such impunity undermined the effectiveness of the public procurement system, frightened honest business and generated corruption schemes and fraud. The Law No. 4738-d obliges customers to respond to the recommendations and comments of the SASU in a mandatory manner (On Amendments to the Law of Ukraine "On Public Procurement" and some Laws of Ukraine on Procurement Monitoring, 2017).

Also, the Law No. 4738-d stipulates that bodies authorized to exercise control in this sphere shall not have the right to intervene in the conduct of procurement procedures.

The decision to start monitoring is taken by the head of the state control body or his deputy on the basis of the data of automatic indicators of risks, information

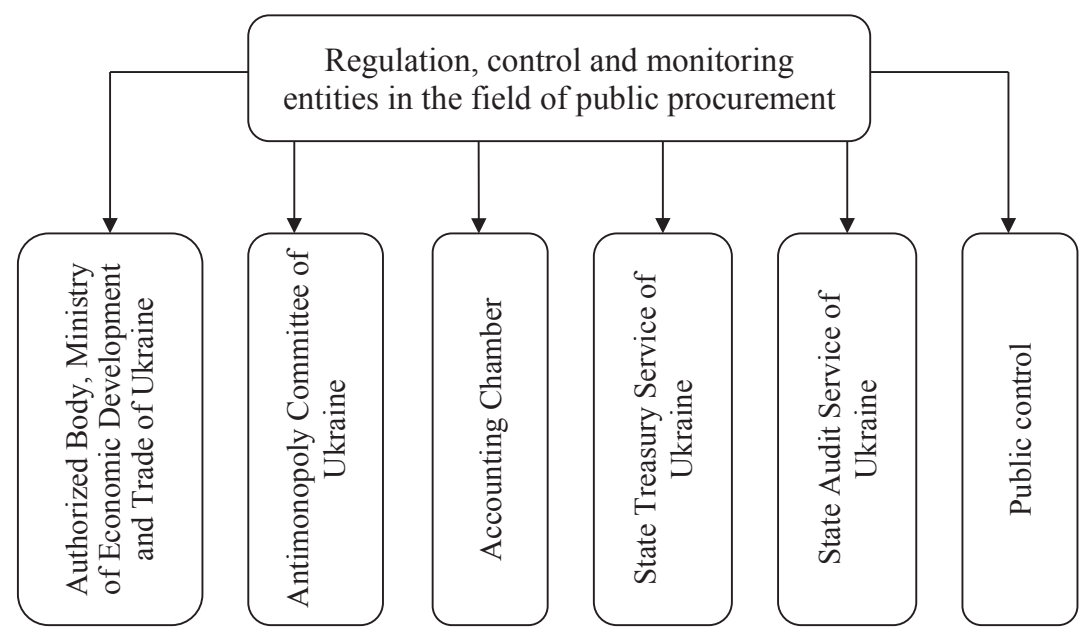

Fig. 2. Authorities authorized to regulate, control and monitor public procurement in Ukraine

Source: compiled by the authors 
received from the authorities, from the media or from public associations, as well as signs of violations of legislation detected by the state financial control body (The Verkhovna Rada introduced a new tool for public procurement monitoring, 2017).

Each tender will now be checked from the announcement to the signing of the contract to meet a number of criteria. At first, there will be 25 such criteria.

Monitoring is expected to last no more than 15 business days. It will be possible to continue it only on the decision of the head of the state control body or his deputy, but not more than for 10 working days.

According to the results of the monitoring, a conclusion will be drawn up that is to be made public in the electronic procurement system within three working days (The Verkhovna Rada has introduced a new public procurement monitoring tool, 2017). This dialogue will be made publicly available in the ProZorro system on the tender card.

In addition, the Law No. 4738-d supplements the first part of Article 1 with a completely new clause, the content of which relates to automatic risk indicators, which are defined as criteria with predetermined parameters, the use of which makes it possible to automatically select procurement procedures that contain signs of violations of the law in the field of Public Procurement (On Amendments to the Law of Ukraine "On Public Procurement" and some Laws of Ukraine on Procurement Monitoring, 2017).

The risk indicator system that will be integrated with ProZorro will automatically search and highlight suspicious procurement, and they will automatically get in the queue for validating by the SASU. In addition to signals of the risk indicator system, the reason to verify procurement will be the appeal of public activists, journalists or representatives of government and local self-government. SASU auditors will be able to check any procurement and on their own initiative (The Verkhovna Rada has passed the law on public procurement monitoring, 2017).

The economic category "Procurement monitoring" has also been revised. Now it is defined as "an analysis of customer compliance with public procurement legislation at all stages of procurement in order to prevent breaches of public procurement law".

Another additional tool that can significantly increase the level of procurement efficiency in Ukraine is the DoZorro monitoring portal (http://dozorro.org/), which was launched on November 1, 2016.

The DoZorro portal combines the efforts of the state, businesses, regulatory authorities and the public. The resource has collected the best world and Ukrainian methods for detecting violations in the field of public procurement. All participants of the portal have access to real effective legal instruments for appealing dubious procurements. The tenderers can evaluate their partners in transactions and leave detailed reviews. On the basis of this information, a rating is automatically generated. And from the profile of each of them, it is clear to what extent the separate user of the system is an honest supplier or purchaser. Such systematic information allows all parties to make rational decisions in activities related to work in the ProZorro system.

The portal was created within the framework of a two-year monitoring program implemented by Transparency International Ukraine with the support of Omidyar Network, Open Government Partnership, and EBRD. The program provides for the creation and development of a monitoring infrastructure around the ProZorro e-Procurement system. In addition to DoZorro, analytical tools are developed based on Qlik Sense (http://bi.prozorro.org/) and Qlik View (http://bipro.prozorro.org/), the system of automatic risk indicators; a new approach to monitoring is developed and tested, using open data and continuously legal support is provided to all ecosystem users (DoZorro public procurement monitoring project launched, 2016).

Implementation of the aforementioned legal acts and control instruments reveals the monitoring of procurement in Ukraine on a completely new quality level.

\section{Findings}

Public procurement is an integral part of the economic processes that are taking place now both in the member states of the European Union and in Ukraine. Despite the fact that the formation of the public procurement market in the EU took place from the middle of the 20th century, and in Ukraine, it is less than 30 years old, fundamental transformations and colossal changes in this sphere are a characteristic feature of the present for both Western and Eastern Europe. But if the EU countries gradually developed a regulatory framework that allowed reform of the public procurement system, prepared a platform for the implementation of the electronic procurement system, Ukraine was forced to go through this difficult path in a short space of time.

In the past few years, the public procurement activities of the Ministry of Economic Development and Trade, regulatory authority, Transparency International Ukraine, civic organisations and representatives of the business environment, volunteers have been aimed at creating an effective mechanism capable of providing procurement system monitoring through the creation of a unique legal and regulatory platforms, as well as a powerful database of real data of purchasers, suppliers, and tenders.

\section{Conclusions}

The implementation of the public procurement system is one of the most successful Ukrainian reforms, 
which became a precedent for the effective interaction of civil society, state, and business. This is explained both by the successful results of reform and by successful communication. Despite the need for further improvement, we can identify a number of positive changes that led to the reform of public procurement.

Firstly, the reform has increased the general awareness of Ukrainian citizens about public procurement. This achievement is important because citizens are the ultimate consumers of public services, as well as those who actually pay for purchased goods through taxes.

Secondly, the reform united all customers, participants, and the Antimonopoly Committee in a single electronic system covering all types of procedures and all stages are outlined by the Public Procurement Law.

The size and inclusivity of the system which covers all users distinguish the Ukrainian e-system from the practice of applying an e-approach individually for each stage (European Commission. e-Procurement Uptake Final Report, 2015) in EU countries.

Thirdly, within the framework of the reform the decentralization of trading platforms took place: as of January 1, 2018, there are 23 accredited trading platforms (for all purchases) instead of one state (ProZorro sites,
2018). Commercialization of this segment has added competition between the sites and should provide continuous improvement of services.

Fourthly, as a part of the e-system and, in order to attract more key players to participate, research and monitoring, open data standards have been used to ensure equality of access to information and allowed all interested parties to monitor the procurement process (Impact of ProZorro, 2017).

Fifthly, the Verkhovna Rada adopted the Law of Ukraine No. 4738-d "On Amendments to the Law of Ukraine "On Public Procurement" and some Laws of Ukraine on Procurement Monitoring" on December 21, 2017. The uniqueness of this law lies in the fact that for the first time in the world, it introduced a system of risk indicators, which will be integrated into ProZorro, which will automatically search and highlight suspicious procurements.

Thus, it can be noted that consolidating the efforts of all stakeholders: will allow ensuring effective competition in Ukraine in the field of public procurement; will lead to the reform of adjacent fields of public procurement; will open for domestic purchasers an opportunity to join not only the European, but also the global market of public procurement.

\section{References:}

Directive 2014/24/EU of the European Parliament. Retrieved from: http://eur-lex.europa.eu/legal-content/EN/ TXT/?uri=CELEX\%3A32014L0024 (accessed 20 January 2018).

Startuvav proekt monitorynhu publichnykh zakupivel DoZorro [DoZorro public procurement monitoring project launched]. Retrieved from: http://me.gov.ua/News/Detail?lang=uk-UA\&id=0ad264d5-761a-4c0a-b34096447256601c\&title=StartuvavProektMonitoringuPublichnikhzakupiveldozorro (accessed 19 January 2018).

European Commission. e-Procurement Uptake Final Report. 2015. Retrieved from: http://ec.europa.eu/ DocsRoom/documents/10050/a achments/1/translations/en/renditions/native (accessed 22 January 2018).

Hellawell, J. M. (1991). Development of a rationale for monitoring. Chapmanand Hall, NewYork, pp. 1-14.

Vplyv Prozorro [Impact of ProZorro]. Retrieved from: http://cep.kse.org.ua/assets/img/articles/Prozorro_ report_ua.pdf (accessed 22 January 2018).

Pro publichni zakupivli : Zakon Ukrainy [On Public Procurement: The Law of Ukraine] No. 922-19 of December 25, 2015.

Pro vnesennia zmin do Zakonu Ukrainy "Pro publichni zakupivli” ta deiakykh zakoniv Ukrainy shchodo zdiisnennia monitorynhu zakupivel : Zakon Ukrainy [On Amendments to the Law of Ukraine "On Public Procurement" and some Laws of Ukraine on Procurement Monitoring: The Law of Ukraine] No. 4738-d of December 21, 2017.

Oxford English Dictionary: the Official site. Retrieved from: http://www.oed.com/(accessed 21 January 2018).

Performance Measurement. Public Procurement. Retrieved from: http://www.sigmaweb.org/ publications/48630147.pdf

Maidanchyky ProZorro [ProZorro sites]. Retrieved from: https://prozorro.gov.ua/majdanchiki-prozorro (accessed 20 January 2018).

Shatkovskyi O., Bruun-Nielsen S. Zvit pro monitorynh derzhavnykh zakupivel [Public Procurement Monitoring Report]. Retrieved from: http://eupublicprocurement.org.ua/wp-content/uploads/2016/07/REPORT-on PP-monitoring_UKR.pdf (accessed 15 January 2018).

Rada vvela novyi instrument monytorynha hoszakupok [The Verkhovna Rada introduced a new tool for public procurement monitoring]. Retrieved from: http://gordonua.com/news/money/rada-vvela-novyy-instrumentmonitoringa-goszakupok-223229.html (accessed 17 January 2018).

Verkhovna Rada ukhvalyla zakon pro monitorynh publichnykh zakupivel [The Verkhovna Rada has passed the law on public procurement monitoring in the first reading]. Retrieved from: https://prozorro.gov.ua/news/verhovnarada-uhvalila-zakon-pro-monitoring-publichnih-zakupivel (accessed 18 January 2018). 